\title{
MARTIN W. FREDERIKSEN
}

\section{$1930-1980$}

In the afternoon of 14 July 1980, Martin Frederiksen was knocked down while crossing the street in Oxford and was killed instantly. A moment of inattention, and a tragedy which has come to his colleagues and to his innumerable friends with a shock that borders on disbelief. He was an accepted and welcome part of the lives of so many of us that it is still hard to understand that tomorrow he will not put his head round the doorway-unexpected and unannounced as always-and that in five minutes time we shall not all be chattering and laughing together as if he had left us only yesterday.

Others will have written elsewhere, with greater authority than I could do, of the loss to classical scholarship which his death entails, not only in England and his beloved Oxford, but also in that other country of his choice, Italy. To say that Italy was his second home is no mere form of words. No other British scholar of our generation has given his heart so thoroughly and with such deep understanding to Italy, to Italian scholarship, and to his countless Italian friends. Understanding: how few of us really achieve it. But Martin (was it some innate gift of his Australian birth and upbringing?) had done so, and it is very proper that these words should appear beside those of an Italian colleague and mutual friend, Fausto Zevi, speaking about this all-important aspect of his life on behalf of Martin's countless Italian friends.

$\mathrm{He}$ was a loyal and devoted friend of the School and all that it stood for. $\mathrm{He}$ first joined us in 1954 as Rome Scholar in Classical Studies and as Craven Fellow. Subsequently, despite all the many calls upon his time within his College and elsewhere in the field of classical studies in Oxford and in Britain, he found time to serve on the Faculty from 1962 to 1966 and again from 1972 to 1976; he was a member of the Library Committee from 1972 to 1977, and Chairman of the Publications Committee from November 1979 until his death. But besides these formal services, on his frequent visits to Rome, whether as a steady visitor or as a bird of passage, he always left us, students and staff alike, the richer for his advice on such matters as book-purchase, the latest news of archaeological events in the south, and of all the complex personalities and pressures which are the stuff of Italian academic life. In the Common Room he had the gift of mixing on equal terms with everyone, from the Director to the most newly fledged of students. It was during his first spell in Rome, in 1954, that I myself had the good fortune to interest him in the School's programme of survey in South Etruria, just at the time when it was still taking shape; and while I like to believe that this experience had a deep effect on his own later work in Italy, I am quite sure, looking back, that much that was best in the South Etruria survey was due to his participation in its formative moments.

Martin was so generous in his friendship, so welcoming and open-hearted in the social intercourse of his everyday life that it took one time to realize that he was also a very private person, reticent to the point of secrecy about himself and his achievements. In time this was something one came to recognize and to accept, even to joke about; but personally I had always imagined that perhaps among his closest Italian friends the curtain was occasionally lifted, and that this was one of the reasons why 
Italy was so essential to him. After talking to several of those friends, however, I realize that they stood exactly where we did, happy to accept him on his own terms, without probing deeper than he was prepared to allow.

Sadly, this reticence extended to his own achievements. Not that there was ever a scholar more open-hearted and generous with his knowledge and his scholarly judgement. 'I must ask Martin what he thinks about this' was a phrase I constantly found on my own lips, and I rarely came away empty-handed. But of his great comprehensive work on classical Campania, the work that was to replace Beloch's Campanien, he rarely spoke as such. Sundry parerga have appeared, to give a taste of its quality, and a few very select friends have been shown finished sections for comment.

What is certain is that Frederiksen's Campania would have taken an honoured place on the bookshelf of every historian of classical Italy and it would have been his lasting memorial. Meanwhile we can only console ourselves with the thought that there are other sorts of memorial no less precious. As his obituary in The Times remarked, he had many friends and no enemies. Wherever he went he left friends, and his was a friendship with a unique flavour of its own, one not easily forgotten. Pupils, colleagues, fellow-researchers, fellow-classicists everywhere, in the memories of each one of us he has left his own special mark of esteem and affection. This is something we shall long treasure.

J.B.W.P.

Martin Frederiksen è morto solo, e il cordoglio è stato universale; Martin aveva vissuto solo, e aveva una cerchia di amici amplissima. Singolare paradosso. Persino il tardivo e quasi fortunoso ritrovamento del suo manoscritto sulla Campania antica - o meglio di quella parte dél lavoro che egli aveva portato alla stesura definitiva - assume, nelle sue modalità, un valore di simbolo.

Martin era amicizia, disponibilità generosa di una mente disinteressata, ma non confidenza; questa restava al dilà di una barriera, e provocarla significava indiscrezione. Tutti lo sapevamo; eppure, alla quasi incredibile notizia della sua scomparsa, tutti ci siamo sorpresi, amici italiani e non, a considerare quanto poco sapessimo di una persona tra quelle a noi care e vicine. Qualcuno ha manifestato il disappunto dell'escluso, i più l'amarezza delle occasioni perdute e ormai irripetibili.

C'era chi lo definiva un Italiano a Oxford, o l'Italiano di Oxford - e non sempre con benevolenza. Definizione inutilmente superficiale. Martin era una figura singolare di intellettuale europeo, starei per dire nel senso settecentesco di questo termine, che non smarriva la consapevolezza delle proprie matrici pur con una capacità di compenetrazione, di umana partecipazione, di cui pochissimi sanno dare esempio. In qualche modo, gli studi di topografia che formano parte importante della sua esperienza scientifica iniziale, danno una chiave del modo suo concreto, diretto, di comprendere dal vivo la realtà del mondo antico; la sua frequente presenza in Italia, a Napoli anzi (Roma era per lui quasi solo una tappa doverosa o un soggiorno di ricerca in biblioteca) segnava in modo personale un approccio alla realtà del paese di cui studiava la storia, in cui è impossibile sceverare interessi di studio e umane inclinazioni.

Martin aveva perciò assunto un ruolo particolarissimo nell'orizzonte dei classicisti non solo italiani e inglesi, quasi di sopranazionale collegamento fra ricercatori e 
scuole diversi e lontani, che, per suo tramite, trovavano un contatto (e un confronto) immediatamente produttivo, svincolato dalle togate sedi dei congressi e delle accademie. Agendo sempre in prima persona, senza prerogative istituzionali, ma anche sempre lontano da ambizioni e interessi particolaristici, Martin svolgeva così un'opera di promozione culturale di cui il tempo che passa ci conferma la valida e profonda portata. La sua libertà di intellettuale lo poneva al disopra di scelte vincolanti di parte; non dimenticheremo di aver avuto il suo nome, accanto ai nostri, in tanti episodi, quando un impegno personale, l'accettare o ricercare collaborazioni, anche scrivere su una rivista, poteva significare una presa di posizione decisa e carica di significati. Quegli anni si vanno allontanando nel tempo, e, nel naturale succedersi delle generazioni, la maggior parte di noi si è a sua volta stabilizzata in sedi di università e di istituti, sovente assorbita più in una routine di amministrazione che in lavoro di scienza, incapace a volte di ritrovare l'unità per un disegno comune. Martin rispettava i ruoli e coltivava gli amici; ma la sua ricerca proseguiva in un costante contatto anche con i più giovani, con una inesaurita freschezza di energie intellettuali, un desiderio di conoscere, di comprendere, che molti tendono prematuramente a smarrire.

Con Martin abbiamo perduto un amico carissimo e uno studioso di grande impegno e statura; ma perdiamo anche un punto di riferimento sempre presente $\mathrm{e}$ vivissimo, il filo di un discorso aperto, condotto, con il fascino di una serenità intellettuale che superava gli schematismi, al dilà di ogni diaframma di linguaggio o di età. Un ruolo, il suo, intenso e personale in cui purtroppo non riusciamo a vedere, oggi, chi possa sostituirlo.

F.Z.

\section{BIBLIOGRAPHY OF MARTIN FREDERIKSEN}

This list contains all MWF's articles, and, I believe, all his major and most minor reviews. I have not, however, sought out his contributions to papers such as The Listener.

1955 J. B. Ward-Perkins. Notes on Southern Etruria and the Ager Veientanus. PBSR 23: 44-72, with an appendix (pages 69-72, inscriptions) by MWF.

1957 MWF and J. B. Ward-Perkins. The Ancient Road Systems of the Central and Northern Ager Faliscus: Notes on Southern Etruria II. PBSR 25: 67-208. Review of A. Aymard-J. Auboyer, Rome et son empire. JRS 47: 251.

1958 Review of G. Camporeale, La terminologia magistratuale nelle lingue osco-umbre. JRS 48: 227-8.

1959 Republican Capua: A Social and Economic Study. PBSR 27: 80-130. Article s.v. 'Puteoli' in Pauly-Wissowa, RE 46, coll. 2036-60.

Review of F. Castagnoli, Le ricerche sui resti della centuriazione. JJRS 49: 167-8. Notice of F. Mancini, G. A. Mansuelli, G. Susini, Imola nell'antichità. $\mathcal{J} R S$ 49: 213 .

1960 Notice of M. Bernardini, Lupiae. $\mathcal{F} R S$ 50: 286.

Notice of P. Arias, S. Aurigemma et al., Studi Sarsinati. $7 R S$ 50: 286.

1961 Review of O. W. von Vacano, The Etruscans in the Ancient World. JRS 51: 242-3. 
Review of U. Kahrstedt, Die wirtschaftliche Lage Grossgriechenlands in der Kaiserzeit. JRS 51 : 250-1.

Notice of T. de Sanctis, Sibaritide a ritrorso nel tempo. $7 R S$ 51: 279.

Notice of M. Brion, Pompeii and Herculaneum: The Glory and the Grief. $\mathcal{F R S}$ $51: 279$.

Notice of A. Boethius, C. Fries et al., San Giovenale: Etruskerna Landet och Folket. $\mathcal{F} R S$ 51: 280.

1962 Review of A. Boethius, The Golden House of Nero. Gnomon 24: 295-99.

Review of Spina e L'Etruria padana and I Piceni e la civiltà Etrusco-Italica. 7RS 52: 264-5.

Review of Cosa 11: the Temples of the Arx by F. E. Brown, E. H. Richardson and L. Richardson. 7RS 52: 266-7.

Notice of La ricerca archeologica nell'Italia meridionale, V. Gongr. del 190 Distretto ..., 1960. JRS 52: 290.

Notice of G. Susini, Fonti Mevaniolensi. JRS 52: 290.

Review of M. McCrum and A. G. Woodhead, Select Documents of the Principates of the Flavian Emperors. Oxford Magazine 1 March.

1964 The Lex Rubria: Reconsiderations. FRS 54: 129-34.

Review of P. MacKendrick, The Mute Stones Speak. JRS 54: 230.

Notice of Atti del VII Congr. Internaz. di Archaeol. Classica. FRS 54: 260.

1965 The Republican Municipal Laws: Errors and Drafts. JRS 55: 183-98.

Towns and Houses: chapter in The Romans, ed. J. P. V. D. Balsdon.

Review of P. Gazzola, Ponti Romani. JRS 55: 289-90.

Review of P. Salway, The Frontier People of Roman Britain. Oxford Magazine 3.

December.

1966 Caesar, Cicero and the Problem of Debt. JRS 56: 128-41.

Review of A. Carcaterra, Intorno ai bonae fidei iudicia. JRS 56: 248-9.

Notice of V. Mellini, Memorie Storiche dell'Isola D'Elba. JRS 56: 276-7.

Review of K.-W. Welwei, Könige und Königtum im Urteil des Polybius. Gnomon 38: 413-4.

Notice of new fascicles of Cambridge Ancient History. Oxford Magazine week 3 Trinity.

1967 Review of J. M. Kelly, Roman Litigation. $\mathcal{J} R S$ 57: 254-6.

1968 Campanian Cavalry: A Question of Origins. Dial. di Arch. 2: 3-31.

Review of E. T. Salmon, Samnium and the Samnites. 7RS 58: 224-9.

Review of G. Charles-Picard, Augustus and Nero: the Secret of Empire, trans. L. Ortzen. Oxford Magazine 10 May.

1969 Notice of P. Sommella, Antichi Campi di Battaglia in Italia. JRS 59: 317-8.

Notice of M. J. T. Lewis, Temples in Roman Britain. Oxford Magazine, 14 February.

1970 Notice of A. W. Lintott, Violence in Republican Rome. EHR 85: 826.

Review of J. H. D'Arms, Romans on the Bay of Naples. Vergilius 16: 46-7.

1971 The Contribution of Archaeology to the Agrarian Problem in the Gracchan Period. Dial. di Arch. 4-5 (1970-1): 330-367.

Review of M. Bonghi-Jovino and R. Donceel, La necropoli di Napoli preromana. JHS 91: 206. 
1973 Review of M. J. Vermaseren, Mithraica I. JRS 63: 274-5.

1974 Review of V. Tran tam Tinh, Le culte des divinités orientales à Herculaneum, and Le culte des divinités orientales en Campanie en dehors de Pompei, de Stabies et d'Herculaneum. JRS 64: $241 \mathrm{f}$.

Review of E. Badian, Publicans and Sinners. EHR 89: 410-11.

1975 Theory, Evidence and the Ancient Economy: review-discussion of M. I. Finley, The Ancient Economy. 7 RS 65: 164-71.

Review of W. Simshauser, Iuridici und Munizipalgerichtsbarkeit in Italien. JRS 65: 191-3.

Review of F. Rakob and Wolf-Dieter Heilmeyer, Der Rundtempel am Tiber in Rom. AJA 79: 393-4.

1976 Contribution on Gell as archaeologist, to Sir William Gell in Italy: Letters to the Society of Dilettanti 1831-1835 (ed. E. Clay in collaboration with Martin Frederiksen) London.

Changes in the Pattern of Settlement [in Republican Italy]. In Hellenismus in Mittelitalien, Kolloquium in Göttingen, 5-9 June, 1974, ed. P. Zanker: 341-355.

Review of P. Sommella and C. F. Giuliani, La Pianta di Lucca Romana. JRS 66: 248-9.

1977 Archaeology in South Italy and Sicily 1973-6. Archaeological Reports (supplement to $\mathcal{F H S}$ ) 1976-77: 43-76.

Una fonte trascurata sul bradisismo puteolano. In I Campi Flegrei nell'archaeologia e nella storia. Atti dei Convegni dell'Accademia dei Lincei 33: 116-29.

Review of R. Duncan-Jones, The Economy of the Roman Empire. $7 R S$ 67: 199-201.

Review of J. von Ungern-Sternberg, Capua im zweiten Punischen Krieg. JRS 67: 183.

1978 Notice of K. Christ, Römische Geschichte: eine Bibliographie, CR 28: 181.

Notice of N. W. Forde, Cato the Censor. CR 28: 182.

1979 The Etruscans in Campania: chapter xi of Italy Before the Romans (eds. D. and F. Ridgway) Academic Press.

Forthcoming publications:

Le gente romane e la conquista d'Italia. In Storia della Società Italiana, ed. E. Lepore et al.

Changes in Agrarian Structures in the Late Republic: Campania. (Istituto Gramsci Seminar, Pisa, Scuola Normale Superiore, 1979, informally circulated: publication pending).

Puteoli e il Commercio di grano nel periodo romano. In a special issue of the Italian journal, Puteoli.

Contribution to the published papers of the 1979 conference on the Elder Pliny at Como.

Naples and the History of Western Greece in the Fifth Century B.c. To appear in a Supplement to Annali dell'Istituto Italiano di Numismatica, probably volume 28.

R. B. Rutherford. 